\title{
WEWNĘTRZNE CZYNNIKI WARUNKUJĄCE DZIAŁALNOŚĆ INNOWACYJNĄ MAŁYCH I ŚREDNICH PRZEDSIĘBIORSTW POWIATU RZESZOWSKIEGO (NA PRZYKŁADZIE BRANŻY ROLNO-SPOŻYWCZEJ)
}

\begin{abstract}
Innowacje są strategicznym bodźcem rozwoju ekonomicznego, a ich realizacją zajmują się jednostki obdarzone przedsiębiorczością, czyli przedsiębiorcy, zatem przedsiębiorczość i innowacyjność to twórcze siły sprawcze rozwoju gospodarczego. Siłą długofalowego rozwoju jest wytrącanie gospodarki ze stanu równowagi przez innowacyjnie zorientowanych przedsiębiorców, dlatego tak ważne, a jednocześnie trudne jest tworzenie optymalnych uwarunkowań działalności innowacyjnej. Działalność innowacyjna w zasadzie opiera się na wszystkich dziedzinach życia gospodarczego, a o jej funkcjonowaniu decyduje nie pojedyncze zjawisko, ale cały ich zbiór. Należy, więc uwzględnić tutaj aspekty ekonomiczne, informacyjne, finansowe, rynkowe, społeczne, instytucjonalne, naukowe, prawne itd. Sektor MSP jest postrzegany coraz częściej jako ważne źródło innowacyjności dla całej gospodarki. Przyczynia się to do poruszania w literaturze przedmiotu kwestii związanych ze sposobem, w jakim małe i średnie przedsiębiorstwa urzeczywistniają i implementują innowacje ${ }^{2}$. Procesy innowacyjne można zaobserwować także w sektorze rolno-spożywczym, który $\mathrm{z}$ uwagi na duże znaczenie w gospodarce narodowej oraz swoją specyfikę produkcji dostaje szczególne wsparcie. Sektor ten w powiecie rzeszowskim koncentruje się głównie w branżach: mięsnej, zbożowej, owocowo-warzywnej, mleczarsko-cukrowniczej i jest jedną z najlepiej rozwiniętych dziedzin gospodarki województwa. Rolnictwo jest obszarem łączącym funkcje: rolniczą, przemysłową oraz turystyczną.

Przedmiotem artykułu jest próba określenia wewnętrznych czynników determinujących innowacyjność małych przedsiębiorstw w branży rolno-spożywczej powiatu rzeszowskiego.
\end{abstract}

Słowa kluczowe: czynniki, działalność innowacyjna, małe i średnie przedsiębiorstwa, powiat rzeszowski, branża rolno-spożywcza.

\section{WPROWADZENIE}

Organizacja, która chce utrzymać się na rynku i być konkurencyjna, musi mieć zdolność do tworzenia innowacji, gdyż to właśnie one decydują o konkurencyjności przedsię-

\footnotetext{
${ }^{1}$ Dr Anna Zych, Państwowa Wyższa Szkoła Zawodowa im. prof. Stanisława Tarnowskiego w Tarnobrzegu, Wydział Nauk Technicznych i Ekonomicznych, ul. Sienkiewicza 50, 39-400 Tarnobrzeg, e-mail: anazych@interia.pl

2 A. Zych, Ekonomiczne bariery rozwoju działalności innowacyjnej przedsiębiorstw (na przyktadzie branży rolno-spożywczej $w$ województwie podkarpackim) [w:] Biznes i spoteczeństwo - finansowe $i$ marketingowe warunki funkcjonowania organizacji, red. P. Maciaszczyk, L. Kaliszczak, P. Szulich, Tarnobrzeg 2015, s. 71.
} 
biorstwa, zaś ich brak może stanowić - i najczęściej stanowi - zagrożenie dla jej istnienia na rynku. Dlatego też innowacje są nierozerwalnie związane z przedsiębiorczością, poprzez dostarczenie lepszych i oszczędniejszych dóbr i usług.

Tworzenie innowacji odbywa się w ramach działalności innowacyjnej, zaś innowacja jest rezultatem procesu innowacyjnego. Jak pisze A.H. Jasiński: „firma jest kluczowym uczestnikiem procesu innowacyjnego, bowiem z jednej strony zgłasza popyt na nowe rozwiązania naukowo-techniczne, a z drugiej - oferuje podaż innowacji technicznych. Współcześnie motorem postępu technicznego nie jest wbrew pozorom naukowiec, lecz innowacyjnie nastawiony przedsiębiorca"3.

Innowacyjne przedsiębiorstwa to takie, które aktywnie poszukują i wykorzystują w praktyce nowe koncepcje, pomysły czy wynalazki, umieją tworzyć lub zdobywać i zbywać nowe produkty lub usługi oraz takie, które charakteryzują się zdolnością do ciągłego adaptowania się do zmian zachodzących w otoczeniu ${ }^{4}$.

Innowacje są strategicznym bodźcem rozwoju ekonomicznego a przedsiębiorczość i innowacyjność to twórcze siły sprawcze rozwoju gospodarczego, dlatego tak ważne, a jednocześnie trudne, jest tworzenie optymalnych uwarunkowań działalności innowacyjnej we współczesnej rzeczywistości gospodarczej. Przedsiębiorstwa podejmujące działalność innowacyjną czynią to dla osiągnięcia określonych celów. Celem o największym i najważniejszym znaczeniu jest rozwój przedsiębiorstwa. Okoliczności zewnętrzne, składające się na otoczenie przedsiębiorstwa wywierają duże znaczenie na budowanie i kształtowanie innowacyjnych zachowań przedsiębiorców, jednakże bardzo ważne, szczególnie w przypadkach małych i średnich przedsiębiorstw, są uwarunkowania wewnętrzne, które zależą od cech osobowości właściciela i kierownictwa przedsiębiorstwa, od zdolności do wykorzystania twórczych postaw i umiejętności pracowników oraz prawidłowego i skutecznego zarządzania zasobami zarówno materialnymi, jak i niematerialnymi przy wykorzystaniu przychylnego otoczenia.

\section{ZAŁOŻENIA METODOLOGICZNE I DOBÓR PRÓBY DO BADAŃ}

Do postawionych celów badania ustalono populację badaną. Głównymi jednostkami losowania były małe i średnie przedsiębiorstwa sektora rolno-spożywczego w powiecie rzeszowskim zgodnie z obowiązującą w Polsce klasyfikacją Głównego Urzędu Statystycznego, natomiast jednostkami badania byli właściciele lub zarządzający tymi przedsiębiorstwami ${ }^{5}$. Z uwagi na sformułowany cel pracy przedsiębiorstwa potraktowano jako pewien jednorodny zbiór, $\mathrm{z}$ równoczesnym wyłączeniem mikroprzedsiębiorstw ${ }^{6}$. Uwagę skoncentrowano tylko na tej grupie firm, gdyż w strukturze sektora MSP stanowią one

${ }^{3}$ A.H. Jasiński (red), Innowacje matych $i$ średnich przedsiębiorstw $w$ świetle badań empirycznych. Promocja XXI, Warszawa 2008, s. 12.

${ }^{4}$ E. Stawasz, Innowacje a mała firma, Łódź 1999, s. 34.

${ }_{5}^{5}$ M. Szreder, Metody i techniki sondażowych badań opinii, Warszawa 2010, s. 43-44.

6 Według podręcznika Oslo zaleca się w badaniach do tyczących działalności innowacyjnej określanie wielkości jednostek na podstawie liczby zatrudnionych pracowników. Zalecenie to jest zgodne $\mathrm{z}$ analogicznymi propozycjami sformułowanymi $\mathrm{w}$ innych podręcznikach $\mathrm{z}$,rodziny Frascati”. W celu zachowania porównywalności danych podręczniki te zalecają zastosowanie następujących klas wielkości: 10-49 zatrudnionych pracowników - przedsiębiorstwa małe; 50-249 - przedsiębiorstwa średnie. 
dominujący udział w działalności innowacyjnej. Ponadto wyróżnia je szczególnie silny związek z lokalnym rynkiem pracy oraz elastyczność w działaniu.

Kryterium doboru określały następujące czynniki łącznie:

- przedsiębiorstwo prowadzące działalność gospodarczą na terenie powiatu rzeszowskiego;

- przedsiębiorstwo zatrudniające od 10 do 249 osób;

- przedsiębiorstwo sektora publicznego lub prywatnego;

- przedsiębiorstwo działające w branży rolno-spożywczej.

Badaniem objęto wszystkie przedsiębiorstwa spełniające powyższe kryteria w oparciu o operat uzyskany na zamówienie z Wojewódzkiego Urzędu Statystycznego w Rzeszowie według rejestru podmiotów gospodarki narodowej REGON ${ }^{7}$. Ze względu na zawarte w rejestrze REGON informacje stanowi on wiarygodny operat losowania w przypadku przedsiębiorstw i instytucji w różnych przekrojach ${ }^{8}$.

Zastosowanie doboru zupełnego jest możliwe w sytuacji, gdy liczebność populacji nie uniemożliwia przeprowadzenia badania w określonych ramach czasowych i finansowych. Uwzględniając fakt, że otrzymany operat obejmował 53 przedsiębiorstwa, przyjęcie wariantu doboru zupełnego uznać należy za w pełni uzasadnione.

Badania właściwe trwały od lutego do kwietnia 2013 roku. W wyniku tak przeprowadzonych badań otrzymano zwrot 45 kwestionariuszy, z których 2 zostały odrzucone po weryfikacji poprawności wypełnienia. Do ostatecznej analizy przyjęto 43 kwestionariusze ankietowe.

W trakcie badania ankietowego respondenci zostali poproszeni o wskazanie natężenia swojej zgody i ocenę stopnia, w jakim wewnętrzne czynniki innowacyjności wpływają na kreowanie i skuteczne komercjalizowanie innowacji.

Wewnętrzne czynniki wpływające na działalność innowacyjną respondenci oceniali w pięciostopniowej skali Likerta:

- 1 - Zdecydowanie negatywny wpływ;

- 2 - Raczej negatywny wpływ;

- 3-Brak wpływu (czynnik neutralny);

- 4 - Raczej pozytywny wpływ;

- 5 - Zdecydowanie pozytywny wpływ.

Im bardziej wskaźnik efektów osiągnie wartość powyżej 3 (prawie taki sam), tym większy będzie pozytywny wpływ poszczególnych składników na działalność innowacyjną. Wskaźnik efektów poniżej 3 będzie pokazywał negatywne oddziaływanie poszczególnych elementów na działalność innowacyjną.

Aby ustalić ostateczny kierunek wpływu siły każdego z poddanych ocenie składników, obliczono średnią arytmetyczną ważoną ${ }^{9}$, nazywaną współczynnikiem oddziaływania S:

${ }^{7}$ Podręcznik Oslo zaleca do tworzenia idealnego operatu korzystanie z urzędowych rejestrów przedsiębiorstw tworzonych do celów statystycznych, takich jak krajowe lub wojewódzkie urzędy statystyczne.

${ }^{8}$ M. Szreder, Metody i techniki..., s. 44-45.

9 Średnią ważoną posługują się również w swoich badaniach: T.C. Powell, TQM as Competitive Advantage, „A Review and Empirical Study, Strategic Management Journal” 1995, No. 1, p. 15-37; M.J. Stankiewicz, Konkurencyjność przedsiębiorstwa. Budowanie konkurencyjności przedsiębiorstwa w warunkach globalnych, Torun 2002, s. 128 i nast.; R. Haffer, Systemy zarzadzania jakościa $w$ budowaniu przewag konkurencyjnych przedsiębiorstw, Toruń 2003, s. 183 


$$
S=\sum_{i=1}^{n} \frac{x_{i} n_{i}}{n_{i}}
$$

gdzie $n_{i}$ - liczebność (częstość bezwzględna, z jaką występuje $i$-ta wartość zmiennej $x$ ).

Następnie na podstawie wartości współczynnika oddziaływania ustalono ranking cech mających wpływ na kreowanie i skuteczne komercjalizowanie innowacji.

\section{CHARAKTERYSTYKA BADANYCH PRZEDSIĘBIORSTW}

Małe i średnie przedsiębiorstwa są coraz częściej postrzeganie jako ważne źródło innowacyjności dla całej gospodarki. Przyczynia się to do poruszania w literaturze przedmiotu kwestii związanych ze sposobami, w jaki małe i średnie przedsiębiorstwa urzeczywistniają i implementują innowacje oraz metod oceny ich innowacyjności ${ }^{10}$.

Wśród przebadanych 48 przedsiębiorców zarządzających małymi i średnimi przedsiębiorstwami sektora rolno-spożywczego w województwie podkarpackim przeważają mężczyźni, którzy stanowią 69,4\%. W grupie badanych respondentów liczebność kobiet jest mniejsza, zarówno w małych, jak i w średnich przedsiębiorstwach. Można jednak zauważyć, iż większość z nich zarządza podmiotami małymi.

Kolejnym czynnikiem warunkującym poziom kompetencji przedsiębiorców jest wykształcenie. Blisko $27 \%$ badanych przedsiębiorców zarządzających małymi i średnimi przedsiębiorstwami legitymuje się wykształceniem średnim technicznym, a kolejne $26,1 \%$ wykształceniem wyższym II stopnia (magister). Badanymi przedsiębiorstwami średnimi zarządzają głównie osoby $\mathrm{z}$ wykształceniem wyższym drugiego stopnia $(24,2 \%)$, wyższym pierwszego stopnia $(5,3 \%)$ oraz średnim technicznym $(5,2 \%)$. Na uwagę zasługuje także fakt, że $100 \%$ badanych respondentów z wykształceniem zawodowym, średnim ogólnokształcącym oraz wyższym trzeciego stopnia kieruje przedsiębiorstwami małymi.

Jeżeli chodzi o wiek właścicieli/zarządzających przedsiębiorstwami, to najliczniejszą grupę stanowią przedsiębiorcy w wieku od 46 do 55 lat oraz powyżej 56 lat. Najmniejszą grupę reprezentują przedsiębiorcy poniżej 25 . roku życia $(0,6 \%)$. Powyższe dane świadczą o tym, iż do własności przedsiębiorstwa dochodzi się w Polsce w wieku dojrzałym, chociaż widać tutaj również wyraźne zaznaczenie się grupy ludzi młodych w strukturze wiekowej właścicieli/zarządzających podmiotami gospodarczymi.

Wśród przebadanych przedsiębiorstw $81,4 \%$ stanowiły podmioty małe, natomiast 18,6\% przedsiębiorstwa średnie (rys. 1).

i nast.; B. Godziszewski, Zasobowe uwarunkowania strategii przedsiębiorstwa, Toruń 2001, s. 141 i nast.; M. Zastempowski, Uwarunkowania potencjatu innowacyjnego polskich matych i średnich przedsiębiorstw, Toruń 2010, s. 168 i nast.

${ }^{10}$ Por. M. Varis, H. Littunen, Types of Innovation, Sources of Information and Performance In Entrepreneurial SMEs, "European Journal of Innovation Management" 2010, Vol. 13, No. 2; K. Hoffman, M. Parejo, J. Bessant, L. Perren, Small firms, R\&D, Technology and Innovation in the UK: a Literature Review, "Technovation" 1998, vol. 18, no. 1; Y.L. Wang, Y.D. Wang, R.Y. Horng, Learning and Innovation in Small and Medium Enterprises, "Industrial Management \& Data Systems" 2010, Vol. 110, No. 2; B. Suku, Incremental Innovation and Business Performance: Small and Medium-Size Food Enterprises in a Concentrated Industry Environment, "Journal of Small Business Management" 2009, Vol. 44, Issue 1. 


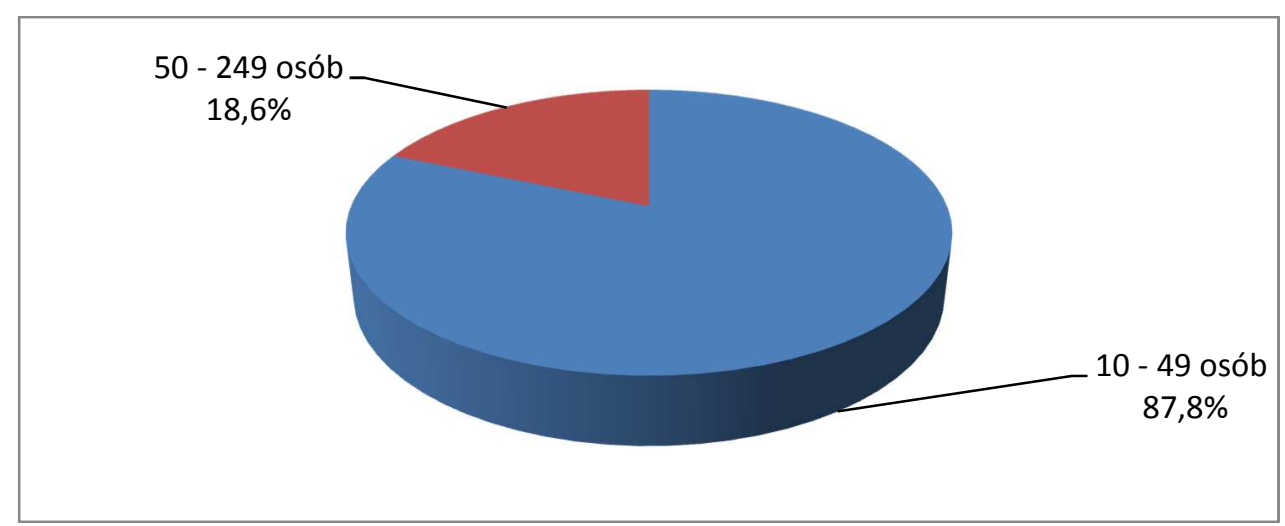

Rys. 1. Struktura badanych przedsiębiorstw według wielkości (w\%)

Źródło: opracowanie własne na podstawie przeprowadzonych badań.

Prawie 72,1\% badanych przedsiębiorstw działa na rynku powyżej 10 lat, blisko 16,3\% funkcjonuje od 6 do 10 lat. Przedsiębiorstwa powstałe w latach 2008-2013, a więc działające na rynku od roku do 5 lat stanowiły 9,3\% badanych podmiotów. Najmniej liczną grupą były przedsiębiorstwa powstałe $\mathrm{w}$ roku 2012, a więc funkcjonujące na rynku od roku (2,3\%). Można zatem wywnioskować, że badane przedsiębiorstwa charakteryzują się dużym stażem działalności na rynku, zatem opinie przedsiębiorców można traktować jako dojrzałe i oparte na długoletnim doświadczeniu.

Najliczniej reprezentowaną wśród badanych podmiotów są przedsiębiorstwa prowadzone przez osoby fizyczne, na podstawie wpisów do ewidencji działalności gospodarczej $(37,2 \%)$. Jest to najprostsza pod względem prawnym forma prowadzenia działalności gospodarczej i jednocześnie są to podmioty o określonej specyfice, której najważniejsze elementy to: niskie nakłady finansowe potrzebne do prowadzenia działalności przez bardzo często przez samego właściciela, który osobiście podejmuje wszystkie decyzje, wąski rodzaj działalności, zorientowanie prowadzonej działalności głównie na członkach rodziny, podejmowanie działań głównie na poziomie lokalnym.

Prawie $22,25 \%$ to spółki cywilne, 20,9\% to spółki z ograniczoną odpowiedzialnością. Najmniej liczną grupę stanowiły przedsiębiorstwa w formie spółki jawnej $(16,28 \%)$ oraz spółki akcyjnej $(3,37 \%)$.

Badane przedsiębiorstwa analizowano również ze względu na rodzaj prowadzonej działalności. Dominującą grupę pośród badanych przedsiębiorstw stanowią podmioty prowadzące działalność produkcyjną, natomiast odnosząc się do zasięgu swego oddziaływania w zakresie zaopatrzenia i sprzedaży, respondenci wyraźnie wskazywali zasięg regionalny i lokalny i krajowy.

\section{WEWNĘTRZNE CZYNNIKI OKREŚLAJĄCE DZIALALNOŚĆ INNOWACYJNĄ BADANYCH PRZEDSIĘBIORSTW}

Analizy wewnętrznych uwarunkowań działalności innowacyjnej małych i średnich przedsiębiorstw sektora rolno-spożywczego w powiecie rzeszowskim dokonano według sześciu grup determinant: finansowych, informacyjnych, rynkowych, produkcyjno/procesowych, organizacyjnych oraz kapitału ludzkiego. 
Pierwszą analizowaną grupą uwarunkowań były czynniki finansowe (tabela 1), z których wydzielono pięć składników.

Analizując oddziaływanie wewnętrznych czynników finansowych poprzez współczynnik oddziaływania S trzeba zauważyć, że wszystkie zostały ocenione przez ankietowanych jako te, które stymulują działalność innowacyjną badanych przedsiębiorstw, bo przecież kapitał posiadany przez przedsiębiorstwa jest oczywistym elementem sukcesu w działalności innowacyjnej. Najsilniej na innowacyjność nadanej populacji oddziałuje wysoki poziom zysku (S=4,51). Jego pozytywny wpływ wskazało 82,9\% ankietowanych. Jako drugi ważny czynnik finansowy respondenci wskazali posiadane rezerwy na ryzykowne $(S=4,32)$, natomiast na trzecim miejscu wskazywano potencjał finansowy przedsiębiorstwa $(\mathrm{S}=4,17)$. Do kluczowych składników finansowych badani właściciele/zarządzający zaliczyli jeszcze wielkość nakładów własnych na badania i rozwój $(S=4,08)$.

Może na to mieć wpływ fakt, że $89 \%$ badanych przedsiębiorstw swoją działalność finansuje za pomocą własnego kapitału, zatem ocena ryzyka inwestycyjnego jest dla nich bardzo ważnym elementem funkcjonowania może ona być określana $\mathrm{z}$ jednej strony przez rodzaj, złożoność, wielkość przedsięwzięcia innowacyjnego oraz z drugiej strony przez umiejętności, doświadczenie i kompetencje pracowników. Im ważniejsze przedsięwzięcie, wymagające większych nakładów finansowych, tym większe korzyści może ono przynieść.

Tabela 1. Wewnętrzne czynniki finansowe i ich wpływ na działalność innowacyjną badanych przedsiębiorstw według współczynnika oddziaływania $S$

\begin{tabular}{|l|c|}
\hline \multicolumn{1}{|c|}{ Wewnętrzne czynniki finansowe } & $\begin{array}{c}\text { Współczynnik } \\
\text { oddziaływania S }\end{array}$ \\
\hline Wysoki poziom zysku & 4,51 \\
\hline Posiadanie rezerw na ryzykowne przedsięwzięcia & 4,32 \\
\hline Potencjał finansowy przedsiębiorstwa & 4,17 \\
\hline Wielkość nakładów własnych na badania i rozwój & 4,08 \\
\hline ŚREDNIA & $\mathbf{4 , 2 7}$ \\
\hline
\end{tabular}

Źródło: opracowanie własne na podstawie przeprowadzonych badań.

Drugim analizowanym obszarem były uwarunkowania informacyjne, czyli strumień komunikacyjny wewnątrz przedsiębiorstwa oraz pomiędzy nim a otoczeniem. Badaniu poddano 10 składników (tabela 2), których wpływ, podobnie jak czynników finansowych, został oceniony przez ankietowanych nieznacznie pozytywnie.

Największy stymulujący wpływ na innowacyjność badanych przedsiębiorstw ma analizowanie sektora działalności w regionie $(S=4,32)$ ora analizowanie sektora działalności w kraju $(S=4,14)$. Wyjaśnienie tego stanu można znaleźć w tym, że $84 \%$ badanych przedsiębiorstw swój zasięg oddziaływania określiło jako lokalny, regionalny i krajowy więc to właśnie tam znajduje się najwięcej informacji potrzebnych przedsiębiorstwom do działania i funkcjonowania na rynku. Na podobnym poziomie zostały ocenione skuteczne systemy informacji $(S=3,99)$ oraz dostęp do informacji specjalistycznej $(S=3,86)$. Na kolejnych miejscach ankietowani wskazali uczestnictwo w targach i wystawach krajowych $(S=3,82)$. Cieszy fakt, że jako czynnik pozytywnie wpływający na innowacyjność przedsiębiorstw ankietowani uznali kontakty z placówkami badawczo-rozwojowymi $(S=3,68)$, 
chociaż współpracuje z nimi tylko $15,1 \%$ badanych podmiotów oraz uczestnictwo w konferencjach naukowych $(S=3,79)$. Na ostatnich miejscach, jako czynniki, które mają najniższy, aczkolwiek pozytywny wpływ na działalność innowacyjną, ankietowani wskazali dostęp do Internetu $(S=3,52)$, uczestnictwo w targach i wystawach międzynarodowych $(S=3,51)$ oraz analizowanie sektora działalności na świecie $(S=3,49)$. Wynika to zapewne z faktu, że większość małych i średnich przedsiębiorstw swoją szczególną uwagę poświęca jednak otoczeniu bliższemu, mimo że wśród badanej populacji 10,2\% przedsiębiorstw funkcjonuje także na rynkach międzynarodowych.

Tabela 2. Wewnętrzne czynniki informacyjne i ich wpływ na działalność innowacyjną badanych przedsiębiorstw według współczynnika oddziaływania S

\begin{tabular}{|l|c|}
\hline \multicolumn{1}{|c|}{ Wewnętrzne czynniki informacyjne } & $\begin{array}{c}\text { Współczynnik } \\
\text { oddziaływania S }\end{array}$ \\
\hline Analizowanie sektora działalności w regionie & 4,32 \\
\hline Analizowanie sektora działalności w kraju & 4,14 \\
\hline Skuteczne systemy informacji & 3,99 \\
\hline Dostęp do informacji specjalistycznej, np. czasopisma & 3,86 \\
\hline Uczestnictwo w targach, wystawach krajowych & 3,82 \\
\hline Uczestnictwo w konferencjach naukowych & 3,79 \\
\hline Kontakty z placówkami badawczo-rozwojowymi & 3,68 \\
\hline Dostęp do Internetu & 3,52 \\
\hline Uczestnictwo w targach, wystawach międzynarodowych & 3,51 \\
\hline Analizowanie sektora działalności na świecie & 3,49 \\
\hline Średnia & $\mathbf{3 , 8 1 2}$ \\
\hline
\end{tabular}

Źródło: opracowanie własne na podstawie przeprowadzonych badań.

W ramach trzeciego analizowanego obszaru, którym były uwarunkowania rynkowe, badaniu poddano 5 składników (tabela 3), których wpływ, podobnie jak czynników finansowych i informacyjnych, został oceniony przez ankietowanych bardzo pozytywnie.

Tabela 3. Wewnętrzne czynniki rynkowe i ich wpływ na działalność innowacyjną badanych przedsiębiorstw według współczynnika oddziaływania $\mathrm{S}$

\begin{tabular}{|l|c|}
\hline \multicolumn{1}{|c|}{ Wewnętrzne czynniki rynkowe } & $\begin{array}{c}\text { Współczynnik } \\
\text { oddziaływania S }\end{array}$ \\
\hline Umiejętność odpowiedzi na potrzeby rynku & 4,22 \\
\hline Znajomość obecnej sytuacji na rynku & 4,19 \\
\hline Umiejętność prognozowania rynku & 4,09 \\
\hline Przeprowadzanie badań rynkowych & 3,99 \\
\hline Dobry marketing pomagający sprzedać innowacje & 3,62 \\
\hline Średnia & $\mathbf{4 , 0 2 2}$ \\
\hline
\end{tabular}

Źródło: opracowanie własne na podstawie przeprowadzonych badań. 
Wśród najważniejszych czynników tej grupy można wymienić umiejętność odpowiedzi na potrzeby rynku $(S=4,22)$. Jego pozytywne oddziaływanie na działalność innowacyjną małych i średnich przedsiębiorstw sektora rolno-spożywczego w województwie podkarpackim wskazało 91,2\% ankietowanych, na co ma wpływ zapewne to, że dla blisko $27 \%$ badanych, innowacje kojarzą się z obserwacją rynku i odpowiedzią na jego potrzeby, natomiast dla prawie 55\% głównym powodem wprowadzania innowacji są właśnie potrzeby rynku i wymuszanie innowacyjności przez klientów.

Na kolejnych miejscach znalazły się dwie z trzech warstw potencjału przedsiębiorstwa - teraźniejszość oraz przyszłość. Pierwszą warstwą jest stan obecny, czyli znajomość obecnej sytuacji na rynku $(S=4,19)$. Na ten czynnik i jego stymulujący dla innowacyjności charakter wskazało 79,8\% respondentów. Drugą warstwą jest natomiast przyszłość, czyli prognozowanie rynku $(S=4,09)$ oraz przeprowadzanie badań rynkowych $(S=3,99)$. Czynniki te i ich kombinacja może doprowadzić do sukcesu przedsiębiorstwa oraz skutecznego i sprawnego generowania rozwiązań innowacyjnych. Ostatnim, analizowanym i ocenionym pozytywnie, w tej grupie czynnikiem jest sfera marketingu i jego wpływ na skuteczną dyfuzję innowacji $(S=3,62)$.

Kolejną grupą uwarunkowań wewnętrznych, poddaną analizie były czynniki o charakterze procesowo-produkcyjnym, które bezpośrednio przekładają się na realizację rozwiązań innowacyjnych. Respondenci oceniali tutaj pięć składników (tabela 4), z których wszystkie zostały ocenione pozytywnie. Do grupy czynników mających największy pozytywny wpływ na działalność badanych przedsiębiorstw na pierwszym miejscu ankietowani zaliczyli predyspozycje do szybkiego dostosowania produkcji do potrzeb rynku $(S=4,25)$. Nieznacznie niżej zostały ocenione zdolności technologiczne przedsiębiorstwa $(\mathrm{S}=4,07)$ oraz możliwość adaptacji nowoczesnej technologii $(\mathrm{S}=4,01)$. Potwierdza to opinię, pojawiającą się w literaturze przedmiotu, że małe i średnie przedsiębiorstwa mają większe zdolności, także technologiczne, pozwalające szybciej i w sposób bardziej elastyczny reagować na pojawiające się na rynku potrzeby.

Tabela 4. Wewnętrzne czynniki procesowo-produkcyjne i ich wpływ na działalność innowacyjną badanych przedsiębiorstw według współczynnika oddziaływania $\mathrm{S}$

\begin{tabular}{|l|c|}
\hline \multicolumn{1}{|c|}{ Wewnętrzne czynniki procesowo-produkcyjne } & $\begin{array}{c}\text { Współczynnik } \\
\text { oddziaływania S }\end{array}$ \\
\hline Predyspozycje do szybkiego dostosowania produkcji do potrzeb rynku & 4,25 \\
\hline Zdolności technologiczne przedsiębiorstwa & 4,07 \\
\hline Możliwość adaptacji nowoczesnej technologii & 4,01 \\
\hline Poziom automatyzacji parku maszynowego & 3,42 \\
\hline Duży wiek parku maszynowego & 2,33 \\
\hline Średnia & $\mathbf{3 , 6 1 6}$ \\
\hline
\end{tabular}

Źródło: opracowanie własne na podstawie przeprowadzonych badań.

Czynniki, które według oceny badanych właścicieli/zarządzających małymi i średnimi przedsiębiorstwami sektora rolno-spożywczego w powiecie rzeszowskim mają nieznacznie pozytywny wpływ na działalność innowacyjną ich przedsiębiorstw to poziom automatyzacji parku maszynowego $(S=3,42)$. Nie dziwi natomiast, że czynnikiem, który w opinii badanych respondentów wpływa najmniej korzystnie na innowacyjność jest duży wiek 
parku maszynowego $(S=2,33)$. A przecież nowoczesna technologia wraz z upływem czasu może przyczynić się do obniżania kosztów wprowadzania rozwiązań innowacyjnych.

Przedostatnią poddaną analizie grupą uwarunkowań były czynniki organizacyjne, w której ocenie poddano 14 składników (tabela 5).

Tabela 5. Wewnętrzne czynniki organizacyjne i ich wpływ na działalność innowacyjną badanych przedsiębiorstw według współczynnika oddziaływania $\mathrm{S}$

\begin{tabular}{|l|c|}
\hline \multicolumn{1}{|c|}{ Wewnętrzne czynniki organizacyjne } & $\begin{array}{c}\text { Współczynnik } \\
\text { oddziaływania S }\end{array}$ \\
\hline Skuteczny i sprawny system zarządzania & 4,22 \\
\hline Umiejętność projektowania rozwiązań innowacyjnych & 4,10 \\
\hline Umiejętność wdrażania rozwiązań innowacyjnych & 4,08 \\
\hline Zdolności organizacyjne kadry kierowniczej & 4,01 \\
\hline Zasięg działalności przedsiębiorstwa & 3,85 \\
\hline Lokalizacja przedsiębiorstwa & 3,82 \\
\hline Posiadane certyfikaty jakości & 3,82 \\
\hline Własne patenty & 3,74 \\
\hline Posiadane licencje & 3,71 \\
\hline Wiek przedsiębiorstwa & 3,62 \\
\hline Wielkość przedsiębiorstwa & 3,50 \\
\hline Posiadanie własnych komórek badawczych & 3,49 \\
\hline Struktura zatrudnionych pracowników & 3,45 \\
\hline Posiadanie strategii innowacji & 3,45 \\
\hline Średnia & $\mathbf{3 , 7 8}$ \\
\hline
\end{tabular}

Źródło: opracowanie własne na podstawie przeprowadzonych badań.

Najistotniejszym czynnikiem wpływającym na działalność innowacyjną badanych przedsiębiorstw jest $\mathrm{w}$ ocenie ankietowanych sprawny i skuteczny system zarządzania $(S=4,22)$, umiejętność projektowania $(S=4,10)$ i wdrażania $(S=4,08)$ rozwiązań innowacyjnych oraz zdolności organizacyjne kadry kierowniczej $(S=4,01)$. Równie ważnymi czynnikami według respondentów są zasięg działalności przedsiębiorstwa $(S=3,85)$ i jego lokalizacja $(S=3,82)$. Do wzrostu innowacyjności badanych przedsiębiorstw mogłyby także przyczynić się posiadane certyfikaty jakości $(S=3,82)$, własne patenty $(S=3,74)$ oraz posiadane licencje $(3,71)$. Niżej, chociaż w pozytywnym znaczeniu według ankietowanych na działalność innowacyjną ich przedsiębiorstw wpływa wielkość $(S=3,50)$ oraz wiek $(S=3,62)$ przedsiębiorstwa. Do mało istotnych składników zaliczyć tutaj można także posiadanie własnych komórek badawczych $(\mathrm{S}=3,49)$ oraz strukturę zatrudnionych pracowników $(S=3,45)$. Według respondentów nieznacznie pozytywnie na działalność innowacyjną wpływa strategia innowacji $(S=3,45)$. Dziwić może więc fakt, że spośród ogółu badanej populacji sformalizowaną strategię w tym zakresie posiada tylko 17,4\% podmiotów.

Ostatnią grupą uwarunkowań poddanych analizie był kapitał ludzki, w którym wyróżniono 6 składników (tabela 6). 
Tabela 6. Czynnik ludzki i jego wpływ na działalność innowacyjną badanych przedsiębiorstw według współczynnika oddziaływania S

\begin{tabular}{|l|c|}
\hline \multicolumn{1}{|c|}{ Czynnik ludzki } & $\begin{array}{c}\text { Współczynnik } \\
\text { oddziaływania S }\end{array}$ \\
\hline Umiejętności, kwalifikacje, wiedza kadry kierowniczej & 4,57 \\
\hline Proinnowacyjne nastawienie kadry kierowniczej & 4,12 \\
\hline Umiejętności, kwalifikacje, wiedza pracowników & 4,08 \\
\hline Kreatywność, pomysłowość pracowników & 4,02 \\
\hline Doskonalenie kwalifikacji pracowników & 3,98 \\
\hline Szkolenia w zakresie innowacyjności, pomysłowości & 3,35 \\
\hline Średnia & $\mathbf{4 , 0 2}$ \\
\hline
\end{tabular}

Źródło: opracowanie własne na podstawie przeprowadzonych badań.

Za najbardziej stymulujące dla działalności innowacyjnej swoich przedsiębiorstw respondenci uznali umiejętności, kwalifikacje i wiedzę kadry zarządzającej $(S=4,57)$ oraz proinnowacyjne nastawienie kadry kierowniczej $(S=4,12)$. Na ten pozytywny wpływ wskazało $74 \%$ badanych respondentów. Taka wysoka ocena tego czynnika może wynikać $\mathrm{z}$ tego, że zdecydowana większość badanej populacji to przedsiębiorstwa małe, w których kadrą kierowniczą są właściciele, podejmujący wszystkie decyzje, również te związane z działalnością innowacyjną.

Kolejnym pozytywnym czynnikiem wpływającym na działalność innowacyjną badanej populacji jest kreatywność i pomysłowość pracowników $(S=4,02)$. Nieco niżej oceniono doskonalenie kwalifikacji pracowników $(S=3,98)$ oraz szkolenia w zakresie innowacyjności, pomysłowości $(\mathrm{S}=3,35)$.

\section{ZAKOŃCZENIE}

Innowacyjność dotyczy teraźniejszości oraz przyszłości, dlatego bardzo ważne jest prognozowanie zmian występujących na rynku oraz umiejętność odpowiadania na jego potrzeby $^{11}$.

Podsumowując, warto przytoczyć także uogólnione wyniki dla poszczególnych grup uwarunkowań działalności innowacyjnej małych i średnich przedsiębiorstw sektora rolno - spożywczego w powiecie rzeszowskim, w oparciu o współczynnik oddziaływania S. Pokazują one, że w opinii ankietowanych badane przedsiębiorstwa posiadają zasoby, które pomagają im w urzeczywistnianiu i implementacji innowacji. Za najważniejsze czynniki wpływające na działalność innowacyjną badani respondenci uznali czynniki finansowe $(S=4,27)$, kapitał ludzki $(S=4,02)$, czynniki rynkowe $(S=4,022)$, czynniki informacyjne $(S=3,812)$ oraz czynniki organizacyjne $(S=3,78)$. Za mniej ważne, ale pozytywnie wpływające, uznali oni czynniki procesowo-produkcyjne $(S=3,616)$.

Natura procesów innowacyjnych jest zagadnieniem złożonym i wielowątkowym. Trudno jest zaproponować dokładny zespół warunków, które określałyby i determinowały skłonność przedsiębiorstw do tworzenia rozwiązań innowacyjnych. Oryginalne i przełomowe innowacje są często efektem stosowania niekonwencjonalnych metod realizacji

11 J. Zrobek, Innowacyjne aspekty rozwoju obszarów wiejskich, „Handel Wewnętrzny” 2014, nr 5, s. 333 i nast. 
projektów badawczo-rozwojowych i wdrożeniowych. Istotnymi czynnikami warunkującymi osiągnięcie sukcesu innowacyjnego są również: niezależność myślenia, fantazja, umiejętność krytycznej oceny rzeczywistości i gotowość do podjęcia ryzyka.

Stosowanie nowych kombinacji zasobów, czyli innowacji wymaga nie tylko odpowiednio zwiększonych środków finansowych, ale również odwagi do podejmowania ryzyka i niepewności, które można minimalizować przez wiedzę i wykorzystanie dostępnej informacji, gdyż wiedza w znaczącym stopniu decyduje o zdolnościach do absorpcji innowacji w odniesieniu do przedsiębiorstw i całej gospodarki.

Dzięki zmianom innowacyjnym przedsiębiorstwo uzyskuje przewagę nad konkurentami i swobodę przewodzenia, a kierownictwo - komfort spokoju i swobodnych poszukiwań okazji do innowacji bez nacisku spraw bieżących. Innowacja jest najlepszym sposobem utrzymywania organizacji na rynku, co bardzo często oznacza również pewność stanowisk kierowniczych. Dla przedsiębiorcy jest ona jedynym narzędziem zapewniającym rozwój i konkurencyjność; daje przedsiębiorcy niezależność, często sukces, wzmaga poczucie jego wartości własnej. Pozwala zatem na stworzenie wokół siebie bezpiecznego obszaru wolności i swobody działania. Tak pojmowane znaczenie innowacji jest niesłychanie ważne w czasach wzrastającego bezrobocia i niepokojów o pracę. Jeśli wziąć pod uwagę wielorakie wymiary znaczenia innowacji, to faktem niepodważalnym staje się stwierdzenie, że zmiany innowacyjne są koniecznością rynkową i warunkiem rozwoju przedsiębiorczości ${ }^{12}$.

W wielu publikacjach poświęconych procesom innowacyjnym wyraźnie oddziela się czynniki zewnętrzne innowacyjności od uwarunkowań wewnętrznych. Niewątpliwie wiele uwarunkowań tworzenia innowacji leży poza przedsiębiorstwem. Są one albo niezależne, albo mało zależne od przedsiębiorstwa. Słuszne jest jednak stwierdzenie, że: „Procesy innowacyjne rzadko zamykają się w ramach pojedynczej firmy, wymagają wspólnie połączenia czynników zewnętrznych i wewnętrznych" ${ }^{13}$.

$\mathrm{Na}$ przyszły rozwój badanych małych i średnich przedsiębiorstw sektora rolno-spożywczego niewątpliwie wpływa wiele barier o różnych tendencjach działania. Innowacyjność i konkurencyjność przedsiębiorstw sektora rolno-spożywczego jest związana i współzależna od wszystkich ogniw agrobiznesu, poziomu rozwoju gospodarki, zamożności miejscowości, na terenie której znajduje się dane przedsiębiorstwo oraz sposobu konkurowania $^{14}$. O tym, które czynniki będą stymulowały, a które ograniczały ich działalność innowacyjną może zdecydować postawa, kwalifikacje i umiejętności osób odpowiedzialnych za przedsiębiorstwa, ale także okoliczności natury prawno-politycznej.

\section{LITERATURA}

[1] Hoffman K., Parejo M., Bessant J., Perren L., Small firms, R\&D, Technology and Innovation in the UK: a Literature Review, "Technovation" 1998, Vol. 18, No. 1.

[2] Firlej K., Ocena konkurencyjności $i$ szans rozwoju przedsiębiorstw przemystu rolnospożywczego $w$ warunkach unijnych, http://www.kpsw.edu.pl/menu/pobierz/RE3/ 13Firlej.pdf (dostęp: 15.01.2013 r.).

12 J. Targalski (red), Przedsiębiorczość i rozwój firmy, Kraków 1999, s. 116.

${ }^{13}$ E. Stawasz, Innowacje a mała firma, Łódź 1999.

${ }^{14}$ K. Firlej, Ocena konkurencyjności i szans rozwoju przedsiębiorstw przemystu rolno-spożywczego $w$ warunkach unijnych, http://www.kpsw.edu.pl/menu/pobierz/RE3/ 13Firlej.pdf (dostęp: 15.01. 2013 r.). 
[3] Jasiński A.H. (red.), Innowacje małych i średnich przedsiębiorstw w świetle badań empirycznych, Promocja XXI, Warszawa 2008.

[4] Stawasz E., Innowacje a mała firma, Wyd. Uniwersytetu Łódzkiego, Łódź 1999.

[5] Suku B., Incremental Innovation and Business Performance: Small and Medium-Size Food Enterprises in a Concentrated Industry Environment, "Journal of Small Business Management" 2009, Vol. 44, Issue 1.

[6] Szreder M., Metody i techniki sondażowych badań opinii, PWE, Warszawa 2010.

[7] Varis M., Littunen H., Types of Innovation, Sources of Information and Performance In Entrepreneurial SMEs, "European Journal of Innovation Management" 2010, Vol. 13, No. 2.

[8] Wang Y.L., Wang Y.D., Horng R.Y., Learning and Innovation in Small and Medium Enterprises, "Industrial Management \& Data Systems" 2010, Vol. 110, No. 2.

[9] Zrobek J., Innowacyjne aspekty rozwoju obszarów wiejskich, „Handel Wewnętrzny” 2014, nr 5.

[10] Zych A., Ekonomiczne bariery rozwoju działalności innowacyjnej przedsiębiorstw (na przykładzie branży rolno-spożywczej w województwie podkarpackim [w]: Biznes i społeczeństwo - finansowe i marketingowe warunki funkcjonowania organizacji, red. P. Maciaszczyk, L. Kaliszczak, P. Szulich, Państwowa Wyższa Szkoła Zawodowa im. prof. Stanisława Tarnowskiego w Tarnobrzegu, Tarnobrzeg 2015.

\section{THE USE OF THE INTERNAL FACTORS OF INNOVATIONS IN SMALL AND MEDIUM - SIZED ENTERPRISES IN RZESZOW COUNTY (BASED ON AGRI-FOOD INDUSTRY)}

The innovations are the strategic stimuli for the economic development. The introduction of innovations is the task for the enterprising units that is, entrepreneurs. Therefore, entrepreneurship and being innovative are the main powers causing the economic development. The force for the long - term development is knocking economics off its balance by business oriented entrepreneurs. Therefore, it is very important to make the optimal conditions for innovative business. Innovative activity is basically based on all branches of economic life. Its functioning is determined not by one, individual phenomenon but the whole its data set. It is necessary to take into account economic, informational, financial, market-based, social, institutional, scientific, legal aspects and so on. Innovation processes might be also observed in agri-food industry which, because of the great importance for national economy and its specific of production, gets its support. This sector in Rzeszow county is concentrated mainly on trades such as: meat, grain and miller's, fruit and vegetables, dairy and confectionary and it is one of the best developed field of economy of the province. Agriculture is the area linking four functions: agricultural, industrial, touristic and recreation.

The subject of the article is the attempt to specify internal factors determining the activity of small and medium - sized enterprises in Rzeszow county (based on agri-food industry).

Keywords: factors, innovations, medium-sized enterprises, Rzeszow county, agri-food industry.

\section{DOI: 10.7862/rz.2017.mmr.12}

Tekst złożono $w$ redakcji: listopad $2016 r$. Przyjęto do druku: marzec 2017 r. 